\title{
Sistem Pendukung Pengambilan Keputusan Pemberian Bantuan dengan Metode AHP
}

\author{
Syahrul Usman ${ }^{1, *}$, Firman Aziz ${ }^{1}$, Muhammad Lutfi ${ }^{2}$ \\ ${ }^{1}$ Fakultas MIPA, Program Studi Ilmu Komputer, Universitas Pancasakti, Makassar, Indonesia \\ ${ }^{2}$ Program Studi Sistem Komputer, STMIK Handayani, Makassar, Indonesia \\ Email: 1," syahrul.usman@ unpacti.ac.id, ${ }^{2}$ firman.aziz@ unpacti.ac.id, ${ }^{3}$ sainteclutfi@ gmail.com \\ Email Penulis Korespondensi: syahrul.usman@unpacti.ac.id
}

\begin{abstract}
Abstrak-Setiap organisasi kemanusian perlu melakukan penggalangan dana dan menyalurkan dana, Penyaluran dana dari para donatur seringkali tidak sesuai dengan program yang telah direncanakan oleh lembaga pelayanan sosial. Penelitian ini bertujuan untuk mengutamakan bantuan logistik untuk para korban bencana banjir dengan menggunakan Metode Analytical Hierarchy Process (AHP) sebagai bahan pendukung yang dapat dijadikan bahan pertimbangan dalam pengambilan keputusan pemberian bantuan pada platform Crowdfunding yang digunakan sebagai media penggalangan dana secara online, Metode AHP digunakan sebagai bahan pendukung untuk menganalisis variabel-variabel acuan yaitu dipertimbangkan dalam membuat keputusan untuk memberikan bantuan. Hasil analisis AHP merekomendasikan urutan calon penerima bantuan dari prioritas tertinggi hingga terendah. Dalam menentukan keputusan membantu dengan memilah calon penerima berdasarkan prioritas, metode AHP menghasilkan nilai rasio konsistensi yang kurang dari 0,1 sehingga dapat disimpulkan bahwa hasil keputusan tersebut memiliki sifat yang konsisten sebagai bahan pendukung pengambilan keputusan.
\end{abstract}

Kata Kunci: Analytical Hierarchy Process (AHP); Platform Crowdfunding; Penggalangan Dana; Penggalangan Dana Online

Abstract-Every humanitarian organization needs to raise funds and channel these funds. Distribution of funds from donors is often not in accordance with the programs that have been planned by social service agencies. This study aims to prioritize logistical assistance for flood disasters using the Analytical Hierarchy Process (AHP) Method as a supporting material that can be taken into consideration in making decisions about providing assistance on the crowdfunding platform which is used as an online fundraising medium, the AHP method is used as a supporting material for analyze the reference variables that are considered in making a decision to provide assistance. AHP analysis results recommend the order of potential beneficiaries from the highest priority to the lowest. In determining assisting decisions by sorting prospective recipients based on priority, the AHP method produces a consistency ratio value that is less than 0.1 so it can be concluded that the results of these decisions have consistent characteristics as supporting materials for decision making.

Keywords: Analytical Hierarchy Process (AHP); Crowdfunding Platform; Fund Distribution; Online Fundraising

\section{PENDAHULUAN}

Setiap lembaga pelayanan sosial pasti membutuhkan dana dalam melakukan berbagai program-program pelayanan baik kepada masyaratak ataupun kepada instansi. Secara umum lembaga pelayanan sosial memperoleh pendanaan yang bersumber dari berbagai donatur baik pemerintah, swasta maupun perseorangan. Namun sering kali dana yang diperoleh penyelenggara dari donatur tersebut tidak mampu untuk mewujudkan program-program yang telah direncanakan oleh suatu lembaga. Salah satu mekanisme yang biasa dilakukan saat penggalangan dana adalah dengan sistem crowdfunding. Secara umum crowdfunding adalah pembiayaan atau pendanaan yang dilakukan secara berkelompok dan melibatkan banyak orang atau dalam istilah bahasa lain biasa disebut joint venture. Crowdfunding merupakan panggilan terbuka, pada dasarnya melalui Internet untuk penyediaan sumber daya keuangan baik dalam bentuk donasi atau sebagai imbalan atas beberapa bentuk penghargaan dan atau hak suara [1]. Crowdfunding yang dimaksud dalam penelitian ini adalah bentuk penggalangan dana menggunakan aplikasi berbasis website sebagai perantara antara donator dan lembaga penyelenggara donasi. Menurut Valanciene dan Jegeleviciute [2], Crowdfunding sebagai aktivitas crowdfunding atau penggalangan dana yang dilakukan melalui internet [3], penggalangan dana mayoritas bersekala kecil dengan mengumpulkan nominal dana dari banyak orang untuk kepentingan yang umumnya menarik hati banyak donator [4] hal ini memiliki kelebihan dan kekurangan, diantara keuntungannya adalah mudah dalam mendapatkan tambahan modal dengan menggunakan platform crowdfunding, Crowdfunding memberikan keuntungan bagi masyarakat terutama bagi masyarakat yang membutuhkan bantuan. Sedangkan kekurangannya adalah tantangan administrasi dan akuntansi yang akan menjadi masalah tersendiri saat menggunakan model crowdfunding dan Resiko penipuan yang dialami penyelenggara akan menurunkan kepercayaan donatur terhadap platform crowdfunding.

Kelemahan Crowdfunding juga disebabkan belum adanya dukungan strategi customer relationship management (CRM) sebagai proses pemasaran, pemeliharaan dan pendekatan yang proporsional kepada para donatur, sehingga pengelola mengalami keterbatasan dalam mengelola strategi pengembangan donatur dan program donasi, dikarenakan karakteristik para donatur dan program unggulan tidak teridentifikasi dengan baik. Oleh karena itu, perancangan website crowdfunding sebagai metode penggalangan dana perlu dilengkapi dengan fungsi CRM sehingga penggalangan dana dan pengelolaan program dapat dilaksanakan secara terpadu meliputi proses pemasaran, pemeliharaan dan pendekatan yang proporsional kepada para donatur. Dengan demikian pengelola donasi dapat menawarkan program donasi yang sesuai kepada para donatur serta dapat mengembangkan program donasi yang tepat. Analisa CRM meliputi identifikasi pelanggan, target pemasaran, loyalitas terhadap 
program dan pengembangan pelanggan (donatur). Salah satu pendekatan yang dapat dilakukan untuk merealisasikan fungsi CRM pada sistem crowdfunding adalah dengan menerapkan metode data mining [5].

Berdasarkan uraian diatas, maka peneliti membangun sistem penggalangan dana terpadu menggunakan model Donation Based Crowdfunding. Model ini adalah standar yang digunakan untuk penggalangan dana dan tidak ada bedanya dengan sedekah. Pengelola tidak mengharapkan kompensasi apapun atas dukungannya terhadap kegiatan tersebut. Sistem Crowdfunding yang dirancang dengan menggunakan metode Analytical Hierarchy Process (AHP) untuk mencari urutan prioritas dari berbagai alternative dalam pemecahan masalah [6], metode AHP sebagai bahan pendukung yang dapat menjadi pertimbangan dalam pengambilan keputusan pemberian bantuan diimplementasikan pada Crowdfunding Platform untuk membangun sistem penggalangan dana secara terpadu.

Sistem pengambilan keputusan (SPK) dirancang dengan menerapkan adaptasi kompetensi yang tinggi agar dapat bisa menjadi wawasan tambahan dalam pengambilan sebuah keputussan [7] juga untuk permasalahan yang sifatnya semi tersturktur (semistructured problem) [8], beberapa peneliti sebelumnya menggunakan metode AHP sebagai metode pendukung dalam sebuah diantaranya Teuku Mufizar, Dede Syahrul Anwar, Rustin Kania Dewi [9] Penelitian ini melakukan perancangan sistem pendukung keputusan dengan menggunakan metode Analytical Hierarchy Process (AHP) menggunakan Bahasa pemrograman JAVA yang dapat mendukung pengolahan data. Hasil akhir dari penelitian ini adalah sistem yang dibangun dapat membantu kerja tim seleksi bantuan dalam menentukan penerima bantuan secara lebih tepat. Azizah, N., Riyanto, DE, \& Adhy, S. [10] merancang sistem pengambilan keputusan dengan mengolah data kondisi lokasi bencana yang menghasilkan rekomendasi bantuan logistik untuk mendukung proses pengambilan keputusan dalam pemberian bantuan logistik Kepada korban banjir di Provinsi Jawa Tengah menggunakan metode AHP dengan mengutamakan bantuan logistik bencana banjir. Penelitian dari Fitri Retrialisca, Yutika Amelia Effendi dan Nania Nuzulita [11], Hasil penelitian ini menghasilkan sistem pendukung keputusan berbasis web dengan menggunakan metode AHP yang dapat digunakan sebagai media uji coba Seleksi Masuk Perguruan Tinggi Negeri Peserta (SBMPTN) untuk mengukur kemampuann peserta didik sebelum mengikuti SBMPTN yang sebenarnya. Utari Wilan, Litasari Widyastuti, Fida Nirmala Nugraha [12] peda penelitian ini penulis melakukan identifikasi untuk key position yang dilakukan dengan pembobotan menggunakan metode AHP untuk mengisi posisi level manager dan supervisor berdasarkan krtiteria key position yang didefinisikan. Kemudian menentukan kriteria talent perusahaan sebagai key position, dan sumber talent bagi perusahaan untuk mancari kandidat. Hasil dari penelitian ini berupa identifikasi di 18 key position dengan tiga kriteria talent tambahan untuk posisi level manager, dan empat kriteria talent untuk posisi supervisor

\section{METODOLOGI PENELITIAN}

\subsection{Desain Penelitian}

Rancangan penelitian ini merupakan penelitian Re-engineering, Re-engineering atau Rekayasa ulang perangkat lunak merupakan salah satu metode yang bisa duguakan untuk mengurangi masalah dengan aplikasi lama, Rekayasa ulang perangkat lunak memungkinkan pemeriksaan dan modifikasi kode perangkat lunak lama yang membantu memelihara, menggunakan kembali, dan mengubahnya [13]. Untuk melakukan Rekayasa ulang perangkat lunak Dalam penelitian ini menggunakan metode pengembangan sistem Model Waterfall, model pengembangan ini baik untuk pengembangan sistem yang memiliki proses bisnis yang dipahami dengan baik dan pekerjaan dapat dilakukan secara linier dari proses inisiasi hingga proses rilis aplikasi, model pengembangan Waterfall adalah model pengembangan perangkat lunak yang menekankan pada tahapan sekuensial dan sistematis, dimulai dari pemetaan spesifikasi kebutuhan yang diikuti dengan proses perencanaan, pemodelan, konstruksi, dan penyebaran [14] Metode ini merupakan salah satu model siklus pengembangan sistem yang biasa dikenal dengan SDLC (System Development Life Cycle) yang meliputi tahapan Planning, Analyst, Design, Development, Testing dan Deployment [15]. Dalam proses perekayasaan penelitian ini menggunakan SDLC dinamakan waterfall karena tahap demi tahap harus dilalui menunggu selesainya tahap sebelumnya dan berjalan secara berurutan [16].

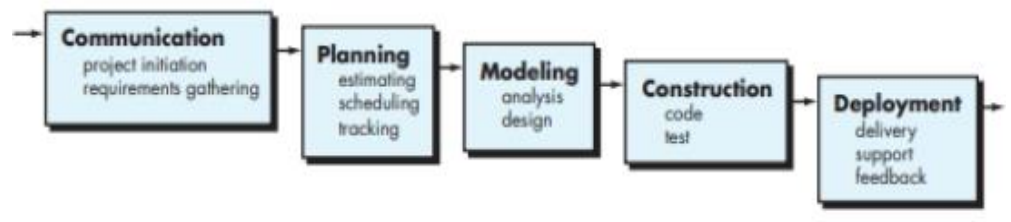

Gambar 1. Waterfall Model [8]

\subsection{Desain Sistem}

\subsubsection{Aliran Sistem Yang Berjalan}

Sistem yang berjalan dapat dituangkan dalam bentuk diagram yang disesuaikan dengan prinsip OOAD (Object Oriented Analysis and Design) menggunakan UML Diagram, berikut Usecase system yang berjalan: 
JURNAL MEDIA INFORMATIKA BUDIDARMA

Volume 5, Nomor 2, April 2021, Page 540-548

ISSN 2614-5278 (media cetak), ISSN 2548-8368 (media online)

Available Online at https://ejurnal.stmik-budidarma.ac.id/index.php/mib

DOI 10.30865/mib.v5i2.2870

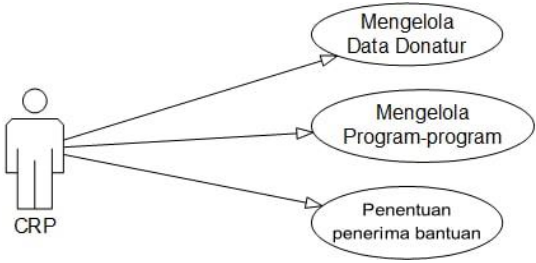

Gambar 2. Usecase diagram sistem yang berjalan

\subsubsection{Aliran Sistem Yang Diusulkan}

Setelah analisa sistem yang berjalan dilaksanakan maka dilakukan desain sistem yang baru. Tujuan utama dari sistem yang baru adalah penyempurnaan dari sistem yang lama atau yang telah ada yang dapat merepresentasikan interaksi antara system dan aktor yang terdiri dari Admin, CRP dan Masyarakat

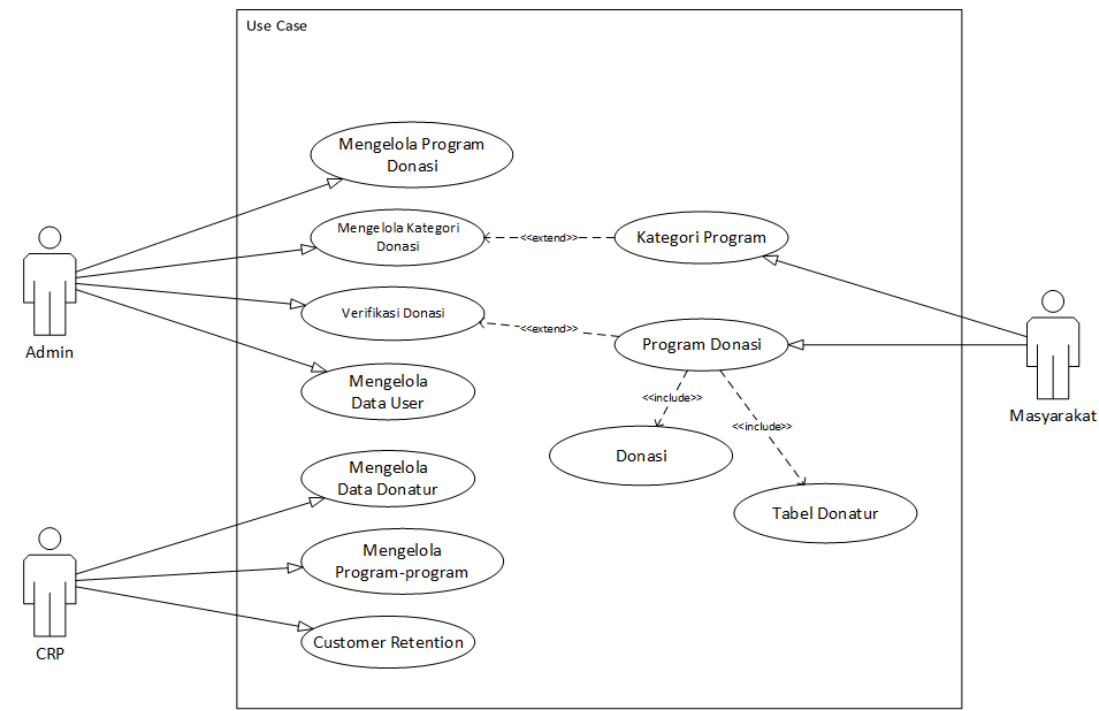

Gambar 3. Usecase diagram sistem yang diusulkan [17]

\subsubsection{Bagan Alir Penelitian}

Berdasarkan Usecase diagram yang diusulkan dapa digambarkan diagram alir penelitian ini pada gambar berikut:

\begin{tabular}{|l|l|l|}
\hline \multicolumn{2}{|c|}{ Diagram Alir } \\
\hline \multicolumn{1}{|c|}{} \\
\hline
\end{tabular}

Gambar 4. Diagram Alir Metodologi Penelitian 


\section{HASIL DAN PEMBAHASAN}

\subsection{Pemodelan Sistem}

Dalam pemodelan desain sistem, item dan komponen dirancang dengan tujuan untuk memudahkan dan mengefektifkan kinerja dan kegiatan kerja serta memberikan gambaran umum tentang bagaimana mekanisme yang tepat untuk merancang sistem sesuai dengan kebutuhan organisasi.

\subsubsection{Usecase Diagram}

Pada use case gambar 3 terdapat empat aktor yaitu admin, CRP, Donatur dan Masyarakat dengan rincian sebagai berikut:

Tabel 1. Rule Aktor Usecase Diagram

\begin{tabular}{|c|c|c|}
\hline Aktor & Deskripsi & Flow \\
\hline Admin & $\begin{array}{l}\text { Mengelolah program donasi, } \\
\text { mengelolah data user }\end{array}$ & $\begin{array}{l}\text { Pengolahan program donasi, pengolahan kategori donasi, } \\
\text { verifikasi donasi, mengelolah data user }\end{array}$ \\
\hline CRP & $\begin{array}{l}\text { Mengelolah data donatur, } \\
\text { mengelolah program, customer } \\
\text { retention. }\end{array}$ & $\begin{array}{l}\text { Mengelolah program-program, customer retention, penentuan } \\
\text { penerima bantuan }\end{array}$ \\
\hline Public & $\begin{array}{l}\text { Kategori program, program } \\
\text { donasi, donasi, tabel donatur. }\end{array}$ & $\begin{array}{l}\text { Untuk mendapatkan informasi kategori program masyarakat } \\
\text { melakukan akses ke halaman depan dari web, informasi kategori } \\
\text { program yang nantinya akan menampilkan beberapa halaman } \\
\text { page }\end{array}$ \\
\hline Donors & $\begin{array}{l}\text { Kategori program, program } \\
\text { donasi, donasi, tabel donatur }\end{array}$ & $\begin{array}{l}\text { nformasi kategori program Donatur melakukan akses ke } \\
\text { halaman depan dari web, informasi kategori program }\end{array}$ \\
\hline
\end{tabular}

\subsubsection{Implementasi dan Pengujian Algoritma}

Tahap ini menjadi pusat perhatian untuk pengembangan CRM. Dimana kepuasan pelanggan (dalam hal ini para donatur) itu penting, yang mengacu pada perbandingan harapan pelanggan dengan persepsi. Salah satu fitur dari algoritma ini adalah fitur pengambilan keputusan yang memberikan bantuan. salah satu tujuan penggalangan dana yaitu menyalurkan bantuannya kepada orang yang tepat dan membutuhkan, berikut tampilan penggunaan metode AHP:

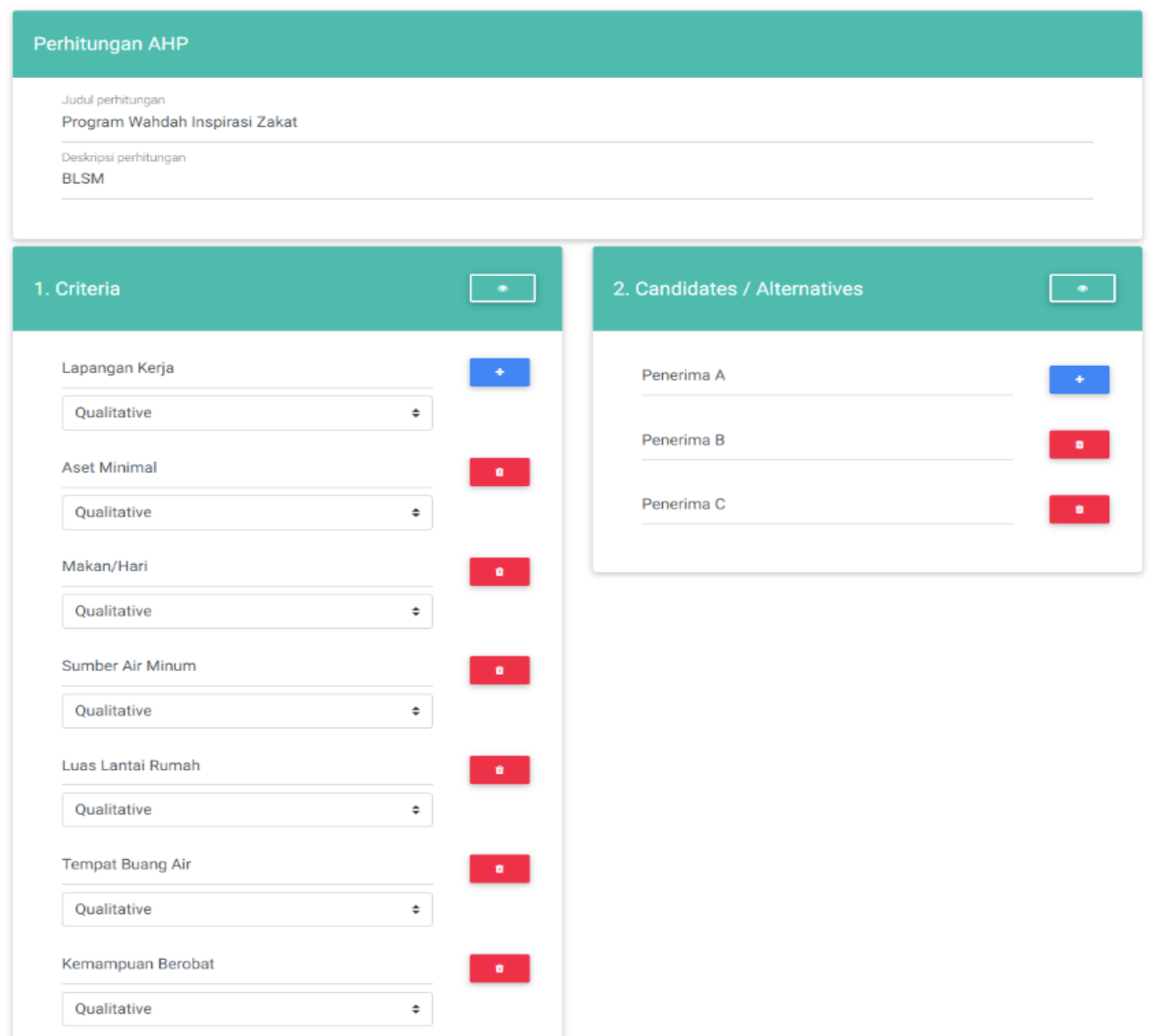

Gambar 5. Tampilan Metode AHP untuk Kriteria, Alternatif dan Matriks 


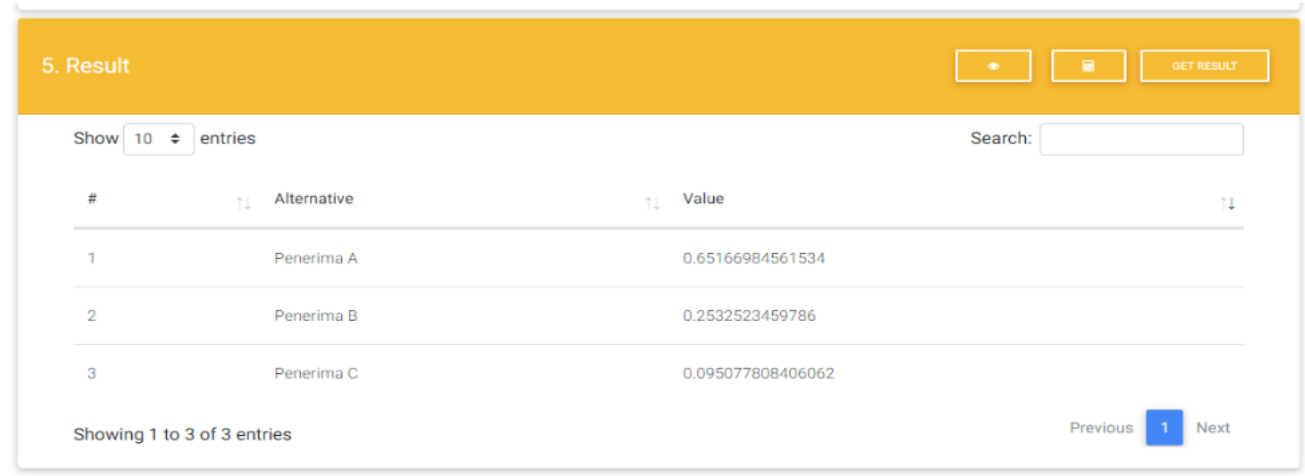

Gambar 6. Tampilan Metode AHP untuk Hasil Perhitungan

Data Kriteria dan alternatif dilakukan perbandingan antar alternative atau perbandingan berpasangan. Untuk berbagai persoalan skala 1 sampai 9 adalah skala terbaik untuk mengekspresikan pendapat [18]. Tabel skala nilai perbandingan dapat dilihat pada Tabel 2 di bawah:

Tabel 2. Referensi Hasil Perhitungan

\begin{tabular}{cc}
\hline Score & Description \\
\hline 1 & Elemen A sama penting dengan elemen B \\
3 & A sedikit leboh penting dari B \\
5 & A jelas penting dari B \\
7 & A sangat jelas penting dari B \\
9 & A mutlak lebih penting dari B \\
$2,4,6,8$ & Apabila ragu-ragu antara dua nilai yang berdekatan \\
\hline
\end{tabular}

Setelah melakukan scoring pada hasil perhitungan maka langkah berikutnya adalah melakukan Penentuan kriteria dan membuat matriks perbandingan kriteria Data Kriteria merupakan data yang menjadi ukuran atau acuan dasar dari penilaian, Pada metode AHP sebuah kriteria dinyatakan penting atau tidak bergantung pada bobot hasil dari perbandingan antar kriteria. Adapun data kriteria yang digunakan yaitu Lapangan Kerja, Aset Minimal, Makan Per Hari, Sumber Air Minum, Luas Lantai Rumah, Tempat Buang Air dan Kemampuan Berobat. Dengan data kandidat teridiri dari Penerima A, Penerima B dan Penerima C, langkah selanjutna penulis melakukan 2 perbandingan yaitu perbandingan kriteria dan perbandingan Pair Wise Kriteria.

a. Matriks Perbandingan Kriteria

Tabel 3. Matriks Perbandingan Kriteris

\begin{tabular}{cccccccc}
\hline$\#$ & $\begin{array}{c}\text { Lapang- } \\
\text { an } \\
\text { Kerja }\end{array}$ & $\begin{array}{c}\text { Aset } \\
\text { Mineral }\end{array}$ & $\begin{array}{c}\text { Makan/ } \\
\text { Hari }\end{array}$ & $\begin{array}{c}\text { Sumber } \\
\text { Air } \\
\text { Minum }\end{array}$ & $\begin{array}{c}\text { Luas } \\
\text { Lantai } \\
\text { Rumah }\end{array}$ & $\begin{array}{c}\text { Tempat } \\
\text { Buang } \\
\text { Air }\end{array}$ & $\begin{array}{c}\text { Kemamp- } \\
\text { uan } \\
\text { Berobat }\end{array}$ \\
\hline $\begin{array}{c}\text { Lapangan Kerja } \\
\text { Aset Mineral }\end{array}$ & 0,41502 & 0,45455 & 0,37578 & 0,24028 & 0,19608 & 0,25610 & 0,32468 \\
Makan/Hari & 0,13834 & 0,03030 & 0,12526 & 0,40046 & 0,15686 & 0,18293 & 0,19481 \\
$\begin{array}{c}\text { Sumber Air } \\
\text { Minum }\end{array}$ & 0,13834 & 0,03030 & 0,02505 & 0,08009 & 0,27451 & 0,25610 & 0,32468 \\
$\begin{array}{c}\text { Luas Lantai } \\
\text { Rumah }\end{array}$ & 0,08300 & 0,03030 & 0,03132 & 0,01144 & 0,03922 & 0,07317 & 0,01299 \\
$\begin{array}{c}\text { Tempat Buang } \\
\text { Air }\end{array}$ & 0,05929 & 0,27273 & 0,02505 & 0,01144 & 0,01961 & 0,03659 & 0,01299 \\
$\begin{array}{c}\text { Kemampuan } \\
\text { Berobat }\end{array}$ & 0,08300 & 0,09091 & 0,04175 & 0,01602 & 0,19608 & 0,18293 & 0,06494
\end{tabular}

b. Perbandingan Antar Alternatif

Langkah selanjutnya melakukan Penetapan prioritas elemen dalam satu persoalan keputusan dengan membuat perbandingan berpasangan antara suatu kriteria yang ditentukan, yakni dengan membandingkan secara berpasangan seluruh elemen untuk setiap elemen untuk setiap sub system hirarki. 
JURNAL MEDIA INFORMATIKA BUDIDARMA

Volume 5, Nomor 2, April 2021, Page 540-548

ISSN 2614-5278 (media cetak), ISSN 2548-8368 (media online)

Available Online at https://ejurnal.stmik-budidarma.ac.id/index.php/mib

DOI 10.30865/mib.v5i2.2870

Tabel 4. Lapangan kerja

\begin{tabular}{ccccc}
\hline$\#$ & A & B & C & AVG \\
\hline Penerima A & 0,652174 & 0,692308 & 0,555556 & 0,633346 \\
Penerima B & 0,217391 & 0,230769 & 0,333333 & 0,260498 \\
Penerima C & 0,130435 & 0,076923 & 0,111111 & 0,106156 \\
Consistency Ratio $=0,04772542503677$ & \\
\hline
\end{tabular}

Tabel 5. Aset Mineral

\begin{tabular}{ccccc}
\hline$\#$ & $\begin{array}{c}\text { Penerima } \\
\text { A }\end{array}$ & $\begin{array}{c}\text { Penerima } \\
\text { B }\end{array}$ & $\begin{array}{c}\text { Penerima } \\
\text { C }\end{array}$ & AVG \\
\hline Penerima A & 0,677419 & 0,714286 & 0,538462 & 0,643389 \\
Penerima B & 0,225806 & 0,238095 & 0,384615 & 0,282839 \\
Penerima C & 0,096774 & 0,047619 & 0,076923 & 0,073772 \\
Consistency Ratio $=$ & 0,083384313481247 & \\
\hline
\end{tabular}

Tabel 6. Makanan Perhari

\begin{tabular}{ccccc}
\hline$\#$ & A & B & C & AVG \\
\hline Penerima A & 0,744681 & 0,789474 & 0,636364 & 0,723506 \\
Penerima B & 0,148936 & 0,157895 & 0,272727 & 0,193186 \\
Penerima C & 0,106383 & 0,052632 & 0,090909 & 0,083308 \\
Consistency Ratio $=0,096089397552888$ & \\
\hline
\end{tabular}

Tabel 7. Air Minum

\begin{tabular}{ccccc}
\hline$\#$ & A & B & C & AVG \\
\hline Penerima A & 0,652174 & 0,692308 & 0,555556 & 0,633346 \\
Penerima B & 0,217391 & 0,230769 & 0,333333 & 0,260498 \\
Penerima C & 0,130435 & 0,076923 & 0,111111 & 0,106156 \\
Consistency Ratio $=$ & 0,04772542503677 &
\end{tabular}

Tabel 8. LUAS LANTAI RUMAH

\begin{tabular}{ccccc}
\hline$\#$ & A & B & C & AVG \\
\hline Penerima A & 0,744681 & 0,789474 & 0,636364 & 0,723506 \\
Penerima B & 0,148936 & 0,157895 & 0,272727 & 0,193186 \\
Penerima C & 0,106383 & 0,052632 & 0,090909 & 0,083308 \\
Consistency Ratio $=$ & 0,096089397552888 &
\end{tabular}

Tabel 9. Tempat Buang Air

\begin{tabular}{ccccc}
\hline$\#$ & A & B & C & AVG \\
\hline Penerima A & 0,652174 & 0,692308 & 0,555556 & 0,633346 \\
Penerima B & 0,217391 & 0,230769 & 0,333333 & 0,260498 \\
Penerima C & 0,130435 & 0,076923 & 0,111111 & 0,106156 \\
Consistency Ratio = & 0,096089397552888 & \\
\hline
\end{tabular}

Tabel 10. Kemampuan Berobat

\begin{tabular}{ccccc}
\hline$\#$ & A & B & C & AVG \\
\hline Penerima A & 0,652174 & 0,714286 & 0,454545 & 0,607002 \\
Penerima B & 0,217391 & 0,238095 & 0,454545 & 0,303344 \\
Penerima C & 0,130435 & 0,047619 & 0,090909 & 0,089654 \\
Consistency Ratio $=$ & 0,018124255398616 & \\
\hline
\end{tabular}

Proses metode AHP mengukur konsistensi pertimbangan dengan consistency ratio. Untuk menghasilkan keputusan yang baik maka diperlukan konsistensi yang baik. Nilai consistency ratio harus kurang dari 0,1. Jika lebih dari rasio batas tersebut, maka nilai perbandingan berpasangan harus dilakukan kembali [19]. Dari proses AHP di atas kita mendapatkan nilai consistency ratio yang kurang dari 0,1 sehingga dapat disimpulkan hasil keputusannya konsisten. Berdasarkan hasil perhitungan dengan AHP, maka diperoleh urutan prioritas penerima bantuan (A, B dan C) sebagai berikut: 
JURNAL MEDIA INFORMATIKA BUDIDARMA

Volume 5, Nomor 2, April 2021, Page 540-548

ISSN 2614-5278 (media cetak), ISSN 2548-8368 (media online)

Available Online at https://ejurnal.stmik-budidarma.ac.id/index.php/mib DOI $10.30865 /$ mib.v5i2.2870

Penerima $\mathrm{B}=0.65166984561534$

Penerima $\mathrm{A}=0.2532523459786$

Penerima $\mathrm{C}=0.095077808406062$

\subsubsection{Pengujian Sistem}

Penelitian ini mnggunakan metode Pengujian white box, Pengujian white box adalah metode desain kasus uji yang menggunakan struktur kontrol desain prosedural untuk mendapatkan kasus uji. Pengujian white box dapat mengungkap kesalahan implementasi seperti manajemen kunci rendah dengan menganalisis cara kerja internal dan konstruksi perangkat lunak. Dari referensi tersebut maka dapat disimpulkan bahwa White Box Testing merupakan salah satu cara untuk menguji suatu aplikasi atau perangkat lunak dengan menganalisis kode dari program yang dibuat apakah salah, berikut gambar flowchart dan Flowgraph pengujuan metode AHP yang digunakan:

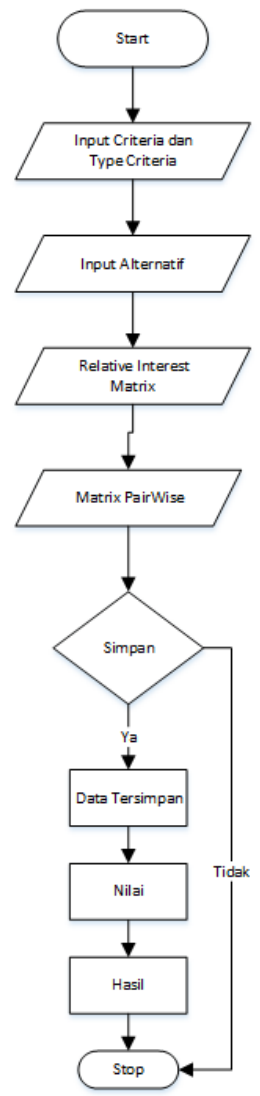

Gambar 7. Flowchart pengujian system metode AHP

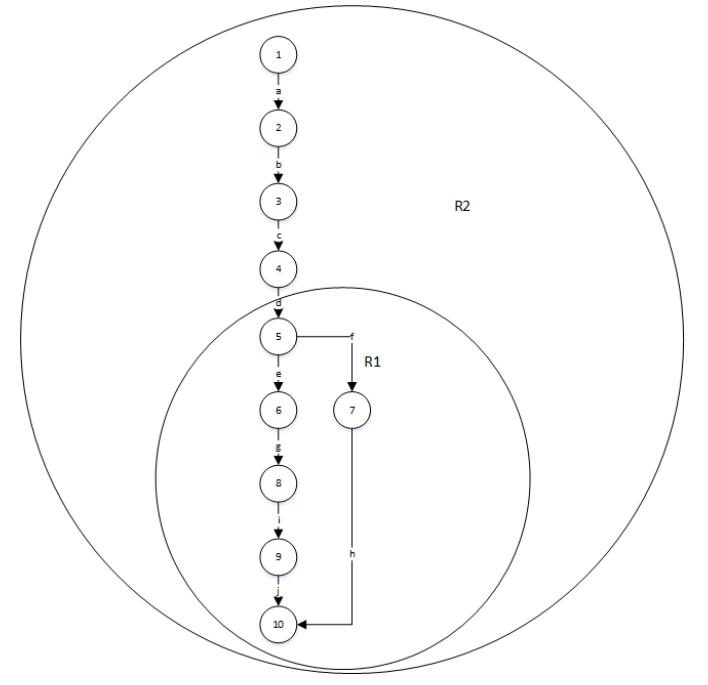

Gambar 8. Flowgraph pengujian system metode AHP 
ISSN 2614-5278 (media cetak), ISSN 2548-8368 (media online)

Available Online at https://ejurnal.stmik-budidarma.ac.id/index.php/mib DOI 10.30865/mib.v5i2.2870

Berdasarkan flowgraph pada gambar 8, maka dapat ditentukan kompleksitas cyclomatic (cyclomatic complexity) serta path dari proses algoritma AHP sebagai berikut:

Dimana:

$$
\begin{aligned}
& \mathrm{V}(\mathrm{G})=\mathrm{E}-\mathrm{N}+2 \\
& \mathrm{~V}(\mathrm{G})=\mathrm{P}+1
\end{aligned}
$$

E : Edge

$\mathrm{N}$ : Node

$\mathrm{P}$ : Predicate node

$$
\begin{aligned}
& E=10 \\
& N=10 \\
& P=1 \\
& \text { Region=2 }
\end{aligned}
$$

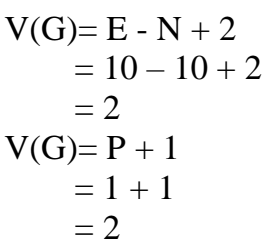

Hasil dari perhitungan kompleksitas cyclomatic merupakan jumlah independent path dari basis path testing yang menunjukkan jumlah pengujian yang harus dijalankan untuk memastikan semua statement pada program dijalankan minimal sekali (semua statement telah diuji).

Menentukan dasar jalur independen

a) Path 1: 1-2-3-4-5-6-8-9-10

b) Path 2: 1-2-3-4-5-7-10

Berdasarkan uraian di atas, terdapat 3 (tiga) aspek yang menjadi fokus bahasan pada penelitian ini, yaitu fitur pengelolaan pelanggan (dalam hal ini donatur), pengembangan strategi pemasaran dan keputusan pemberian bantuan. fitur keputusan pemberian bantuan diimplementasikan dengan algoritma AHP. Integrasi antara fitur pengelolaan donatur dengan fitur pengembangan strategi pemasaran menghasilkan fungsi rekomendasi prioritas e-mail marketing kepada para donatur, sebagai upaya untuk menginformasikan program donasi sesuai dengan riwayat/ preferensi donatur.

\section{KESIMPULAN}

Sistem ini dirancang mengikuti model Crowdfunding Berbasis Donasi untuk memudahkan pengelolaan donatur dan mengembangkan strategi pemasaran program donasi. Metode Analytical Hierarchy Process (AHP) sebagai pendukung yang dapat memberikan bahan pertimbangan dalam pengambilan keputusan dengan memilah calon penerima bantuan berdasarkan prioritas. Dari proses Metode Analitik Pada Proses Hirarki didapatkan rasio konsistensi yang sama yakni kurang dari 0,1 sehingga hasil keputusan dapat disimpulkan konsisten.

\section{REFERENCES}

[1] P. Belleflamme, T. Lambert, and A. Schwienbacher, "Crowdfunding: An Industrial Organization Perspective.” 2010, [Online]. Available: https://economix.fr/uploads/source/doc/workshops/2010_dbm/Belleflamme_al.pdf.

[2] L. Valančienè and S. Jegelevičiūtè, "VALUATION OF CROWDFUNDING: BENEFITS AND DRAWBACKS," Econ. Manag., vol. 18, no. 1, 2013, doi: 10.5755/j01.em.18.1.3713.

[3] E. Evangelista, "Perlindungan Hukum Bagi Donatur Dalam Penyelenggaraan Donation based crowdfunding di Indonesia," Kumpul. J. Mhs. Fak. Huk., vol. 0, no. 0, 2019, [Online]. Available: http://hukum.studentjournal.ub.ac.id/index.php/hukum/article/view/3543.

[4] O. Andrea, M. Lucia, P. Marta, and P. A., "Crowd-funding: transforming customers into investors through innovative service platforms," J. Serv. Manag., vol. 22, no. 4, pp. 443-470, Jan. 2011, doi: 10.1108/09564231111155079.

[5] W. M. S. Rizal F. Aji, "Strategi pengembangan donatur pada lembaga amil Zakat dengan pendekatan data mining = Donor development strategy at the institute Amil Zakat with data mining approach," Universitas Indonesia Library. 2011, [Online]. Available: http://lontar.ui.ac.id/detail?id=20172095\&lokasi=lokal\#parentHorizontalTab1.

[6] S. Hartati and A. Nugroho, "Sistem Pendukung Keputusan Berbasis Ahp (Analytical Hierarchy Process) Untuk Penentuan Kesesuaian Penggunaan Lahan (Studi Kasus: Kabupaten Semarang),” J. Inform. Ahmad Dahlan, vol. 6, no. 2, 2012.

[7] A. A. Chamid, B. Surarso, and F. Farikhin, "Implementasi Metode AHP Dan Promethee Untuk Pemilihan Supplier," J. Sist. Inf. Bisnis, vol. 5, no. 2, pp. 128-136, 2015, doi: 10.21456/vol5iss2pp128-136.

[8] E. Turban, J. E. Aronson, and T.-P. Liang, Decision Support Systems and Intelligent Systems (7th Edition). USA: Prentice-Hall, Inc., 2004.

[9] T. Mufizar, D. S. Anwar, and R. K. Dewi, "Pemilihan Calon Penerima Bantuan Siswa Miskin Menggunakan Metode Analytical Hierarchy Process (AHP)," Creat. Inf. Technol. J., vol. 4, no. 1, p. 30, 2016, doi: 10.24076/citec.2016v4i1.93. 
JURNAL MEDIA INFORMATIKA BUDIDARMA

Volume 5, Nomor 2, April 2021, Page 540-548

ISSN 2614-5278 (media cetak), ISSN 2548-8368 (media online)

Available Online at https://ejurnal.stmik-budidarma.ac.id/index.php/mib

DOI 10.30865/mib.v5i2.2870

[10] N. Azizah, D. E. Riyanto, and S. Adhy, "Sistem Pendukung Keputusan Pemberian Bantuan Logistik Bencana Banjir di Jawa Tengah Berdasarkan Proses Hierarki Analitik," J. Informatics Technol. Vol 2, No 3 Wisuda Agustus 2013, vol. 2 , no. 3, pp. 34-41, Sep. 2014, [Online]. Available: https://ejournal3.undip.ac.id/index.php/joint/article/view/6291.

[11] F. Retrialisca, Y. A. Effendi, and N. Nuzulita, "Decision Support System and Recommendation on SBMPTN Try-Out with Analytic Hierarchy Process (AHP)," in 2019 International Conference on Computer Science, Information Technology, and Electrical Engineering (ICOMITEE), Oct. 2019, pp. 169-174, doi: 10.1109/ICOMITEE.2019.8921040.

[12] U. Wilan, L. Widyastuti, F. N. Nugraha, P. Studi, T. Industri, and F. R. Industri, "Metode Analytic Hierarchy Process ( Ahp ) Dan Kriteria Profil Kompetensi Talent Key Position Pada Pt . Industri," vol. 1, pp. 31-36, 2014.

[13] Pavel Ilyusenko, "Held Back by Legacy Software? Reengineering Can Help To Fuel Change," Scnsoft.com. https://www.scnsoft.com/blog/legacy-software-reengineering-guide (accessed Mar. 08, 2021).

[14] M. A. Rather and V. Bhatnagar, "A COMPARATIVE STUDY OF SOFTWARE DEVELOPMENT LIFE CYCLE MODELS," Int. J. Appl. or Innov. Eng. Manag., vol. 4, no. 10, pp. 24-26, 2015, [Online]. Available: https://www.researchgate.net/publication/305863548_A_comprative_study_of_sdlc_model.

[15] R. Pressman and B. Maxim, Software Engineering: A Practitioner's Approach, 8th Ed. 2014.

[16] Y. Bassil, "A Simulation Model for the Waterfall Software Development Life Cycle.” 2012.

[17] Muhamaad Lutfi; Hazriani; Yuyun, "Platform Crowdfunding E-AidPatory: Platform Untuk Membangun Sistem Penggalangan Dan Penyaluran Bantuan Secara Partisipatif," EC00202027436, 2020.

[18] Fitria, "ANALYTIC HIERARCHY PROCESS METODE PENDUKUNG KEPUTUSAN PEMBERIAN KREDIT PADA KOPERASI MANDIRI UTAMA,” J. Inform., vol. 13, no. 1, pp. 10-22, 2013, doi: 10.1079/9780851994017.0231.

[19] R. de L. E. Padmowati, "Pengukuran Index Konsistensi Dalam Proses Pengambilan Keputusan," Semin. Nas. Inform. vol. 2009, no. semnasIF, pp. 80-84, 2015. 